\title{
Phaseolus beans: impact on glycaemic response and chronic disease risk in human subjects
}

\author{
Andrea M. Hutchins ${ }^{1 *}$, Donna M. Winham ${ }^{2}$ and Sharon V. Thompson ${ }^{3}$ \\ ${ }^{1}$ Department of Health Sciences, University of Colorado Colorado Springs, 1420 Austin Bluffs Parkway, Colorado Springs, \\ CO 80918, USA \\ ${ }^{2}$ Nutrition Program, School of Nutrition and Health Promotion, 500 North 3rd Street, Phoenix, AZ 85004, USA \\ ${ }^{3}$ Center for Research on Occupational and Environmental Toxicology, Oregon Health E Science University, 3181 Southwest \\ Sam Jackson Park Road, Portland, OR 97239, USA
}

(Submitted 15 September 2011 - Accepted 1 December 2011)

\section{Abstract}

Consumption of Phaseolus vulgaris bean species such as pinto, black, navy or kidney may be beneficial in the prevention and treatment of chronic diseases. In particular, conditions that are promoted by increased glycaemic stress (hyperglycaemia and hyperinsulinaemia) including diabetes, CVD and cancer seem to be reduced in individuals who eat more of these beans. The present paper discusses the influence of $P$. vulgaris species on glycaemic response and the impact that relationship may have on the risk of developing diabetes, CVD and cancer.

\section{Key words: Phaseolus vulgaris: Beans: Glycaemic response: Chronic disease: Human subjects}

Consumption of the Phaseolus vulgaris species of beans may be beneficial in the prevention and treatment of chronic diseases that are promoted by increased glycaemic stress (hyperglycaemia and hyperinsulinaemia). These conditions include diabetes and CVD, as well as cancer.

The importance of controlling postprandial blood glucose in the prevention and management of chronic disease has gained recognition in recent years ${ }^{(1-3)}$. Glucose elevations cause oxidative stress that then alters the ability of the lining of blood vessels, or endothelium, to respond appropriately to blood flow. Some foods such as beans appear to stabilise or reduce postprandial glucose variability. Epidemiological studies show associations with increased legume consumption and decreased rates or prevalence of chronic diseases such as type 2 diabetes mellitus (T2DM) ${ }^{(4-6)}$. Most beans such as the common bean ( $P$. vulgaris sp., for example, pinto bean, black bean, navy bean) have a low glycaemic index $(\mathrm{GI})^{(7,8)}$. In contrast, high-GI items such as white rice and white bread can elevate postprandial glucose and result in increased oxidative $\operatorname{stress}^{(9-11)}$

The low glycaemic response of beans alone has been documented $^{(9,12)}$, but few studies have looked at the acute effects of P. vulgaris or common beans on glycaemic response as part of a meal ${ }^{(8,13)}$. In the limited number of studies that have looked at mixed meals, beans combined with a highGI or refined carbohydrate food produced a glycaemic response that was in between the GI of the two foods when analysed alone ${ }^{(8,13,14)}$. It is not clear what kind of synergistic effects are produced or if an intermediate value always exists when the composition of the foods is varied. These findings are important for guiding recommendations to improve diabetes control and lower CVD and cancer risk ${ }^{(10)}$. It is possible that adding a low-GI food may reduce damage produced by other high-GI components of that meal. One important consideration is that we do not know the magnitude of the effect. It also appears that the glycaemic response attenuation is not necessarily linear.

The present paper discusses the relationship between glycaemic concentrations and glycaemic response produced by the consumption of $P$. vulgaris species, and the impact that relationship may have on the risk of developing diabetes, CVD and cancer. Glycaemic concentration refers to blood glucose measures at a particular point in time (for example, fasting) and glycaemic response is defined as blood glucose

Abbreviations: GI, glycaemic index; GL, glycaemic load; T2DM, type 2 diabetes mellitus.

*Corresponding author: Associate Professor A. Hutchins, fax +1 719255 4433, email andrea.hutchins@uccs.edu 
concentration following meal consumption, which is established by the rate at which glucose is released into and subsequently removed from circulation ${ }^{(15)}$.

\section{Review methods}

The electronic databases $\mathrm{MEDLINE}^{\circledR}, \mathrm{CINAHL}^{\circledR}$ and the Cochrane Library were searched in November 2010, May 2011 and August 2011 with no date limitations. Keywords used for the search were 'Phaseolus vulgaris', 'beans', 'legumes' and 'glycaemic response'. Abstracts of articles identified as potentially relevant based on the use of the terms Phaseolus vulgaris, beans, or legumes and glycaemic response in the abstract or keywords were obtained. The 1438 article abstracts were then reviewed to determine if the article investigated the impact of $P$. vulgaris on glycaemic response or the prevention or treatment of diabetes mellitus, heart disease, CVD, obesity, weight management or cancer. Relevant articles ( $n$ 118) were then collected in full text.

The full-text articles were screened for inclusion based on the following criteria: (1) published in a scientific peerreviewed journal; (2) used P. vulgaris as a sole treatment or as part of a treatment; (3) published in English; (4) addressed the impact of $P$. vulgaris on glycaemic response or prevention or treatment of diabetes mellitus, CVD or cancer; (5) used human subjects; and (6) not an editorial, expert opinion, review or instructive article. The reference lists of included articles, review articles and meta-analyses were hand-searched for articles that met the inclusion criteria but that had not been identified during the electronic database search. Relevant articles from the reference lists that met the inclusion criteria were collected in full text. We found twenty-three articles meeting the criteria for inclusion in the tables in the present review.

\section{Evidence for health outcomes}

\section{Evidence that beans induce low glycaemic response}

Beans and other dry grain pulses typically reduce postprandial glucose elevations in short-term studies with nondiabetic and diabetic individuals compared with most starch foods ${ }^{(13,14,16-23)}$. Most studies that examined the impact of legumes on glycaemic control have utilised either normoglycaemic or T2DM participants.

The lower glycaemic response to beans has been attributed to their low GI or delayed digestion of the carbohydrate within and, therefore, delayed absorption of glucose $\mathrm{e}^{(7,8,10,12-14)}$. One important question to address, however, is determination of the magnitude and nature of the effect of beans on the glycaemic response to meals containing high-GI foods. The few studies that have explored this question generally report that beans combined with a highGI food produce a glycaemic response that is intermediate between the high- and low-GI foods, but this is not to say that the nature of the effect is additive or linear ${ }^{(8,13,14,17,19-22)}$.

The mixed-meal findings presented in Table 1 have important implications for chronic disease risk reduction ${ }^{(10,24)}$.
Individuals generally consume foods in combination, not in isolation, so determining the overall glycaemic response to the combination of foods has greater 'real-life' application to determining chronic disease risk reduction. Demonstrating that inclusion of beans in a meal results in a lower glycaemic response to the meal will provide a realistic, food-based mechanism for reducing the oxidative stress, endotheliumdependent vasodilation, and increased blood pressure associated with increased risk for some chronic diseases such as T2DM, complications of T2DM and CVD. Further research is required to examine the lower glycaemic response associated with bean meals along with changes in oxidative stress, endothelium-dependent vasodilation and blood pressure to confirm the validity and strength of this relationship. These studies should be adequately powered randomised controlled trials lasting at least 6 weeks in order to effectively assess the impact of beans' ability to lower the glycaemic response on these markers for chronic disease risk.

Impact of Phaseolus vulgaris species and glycaemic response on type 2 diabetes mellitus and risk factors for type 2 diabetes mellitus

Controlling postprandial glucose increases through incorporation of low-GI foods such as P. vulgaris sp. has a favourable impact on glucose control. Studies demonstrating that consumption of low-GI foods such as beans improve glucose control and T2DM control, as well as reduce risk for developing T2DM, have been analysed and summarised elsewhere and will be covered briefly in the present review ${ }^{(25-27)}$. A recent Cochrane review assessed eleven randomised controlled trials and determined the effects of low-GI or lowglycaemic load (GL) diets and found that they improve glycaemic control in individuals with diabetes ${ }^{(28)}$. Their positive conclusions are supported by other meta-analyses ${ }^{(29,30)}$ which demonstrated reductions in HbA1c of 0.27 (95\% CI -0.5 , $-0.03)^{(30)}$ to $0.43(95 \% \mathrm{CI} 0 \cdot 13,0.72)^{(29)}$ when low-GI diets were compared with high-GI diets. The reductions in $\mathrm{HbA}_{1 \mathrm{c}}$ achieved with a low-GI diet are comparable with those produced by pharmacological interventions (for example, hypoglycaemic medications) ${ }^{(29)}$. However, the studies included in these reviews treated low-GI, or low-GL, diets in a more global fashion and did not focus solely on beans.

A meta-analysis ${ }^{(7)}$ examined forty-one studies that examined the effects of legume consumption alone, legume consumption as part of a low-GI diet, and legume consumption as part of a high-fibre diet. Pooled analyses demonstrated that legumes, alone or in low-GI or high-fibre diets, improve markers of longer-term glycaemic control ( $\mathrm{HbA}_{1 \mathrm{c}}$ and fructosamine). Of the reports from the meta-analysis ${ }^{(7)}$ that focused on $P$. vulgaris consumption, seven ${ }^{(31-37)}$ are summarised in Table 2. These results are encouraging news for individuals with or at risk for T2DM since they indicate that simple diet changes, such as the inclusion of beans, can have a positive impact on glycaemic control. Nevertheless, these studies also illustrate the fact that few studies have focused on how bean intake influences risk factors for or the treatment of T2DM, let alone whether their effect is linked solely to the lower 


\section{N British Journal of Nutrition}

Table 1. Impact of Phaseolus vulgaris species on glycaemic response

reference Design $\quad$ Sample size $\quad$ Population

(1) Gl studies with the same amount of carbohydrate in test food as control (a) Whole beans

$\begin{array}{ll}\begin{array}{l}\text { Bornet } \\ \text { et al. }\end{array} & \text { Randomised } \\ \text { cross-over }\end{array}$

et al.

trial

Eighteen

Men and

$(1987)^{(13)}$

adults

women
T2DM

(2) Single-meal postprandial studies (a) Whole beans

$\begin{array}{lr}\text { Jenkins } & \text { Randomised } \\ \text { et al. } & \text { controlled } \\ (1980)^{(16)} & \text { cross-over }\end{array}$

$\begin{array}{ll}\text { Groups of } & \text { Healthy men } \\ \text { between five } & \text { and women } \\ \text { and } & \\ \text { ten adults } & \end{array}$

trial

ten adults

Treatment

Results

Conclusions

consumed
on separate

days

$$
\begin{aligned}
& \text { Test foods: } \\
& \text { White bread } \\
& \text { White rice } \\
& \text { Wheat flour spaghetti } \\
& \text { Kidney beans } \\
& \text { Lentils } \\
& \text { Potato flakes } \\
& \text { Foods consumed alone } \\
& \text { or as part of iso-glucido- } \\
& \text { lipido-protidic meal } \\
& \text { All foods and meals } \\
& \text { provided } 50 \mathrm{~g} \text { available } \\
& \text { carbohydrate }
\end{aligned}
$$

Eight legumes
and twenty-
four foods
consumed
on separate

days

Thirty-two foods:

Beans:

Butter beans

Haricot beans

Kidney beans

Soyabeans
Blackeye peas

Chickpeas

Marrowfat peas

Lentils

Tubers:

New potato

Sweet potato

Yams

Grains:

Buckwheat

Millet

Brown rice

White rice

Sweetcorn

Bread and pastas:

White bread

Wholemeal bread

White spaghetti

Brown spaghetti

Ryvita

Breakfast cereals:

All-Bran

Cornflakes

Muesli

Porridge oats

Shredded Wheat

Weetabix

Biscuits:

Digestive
Gl of single foods:

White bread $>$ potato flakes $>$

wheat flour spaghetti $>$ white

rice $>$ lentils $>$ kidney beans

$(P<0.001)$

Gl of test meals:
White bread $>$ potato flakes $>$

White bread $>$ potato flakes
white rice $>$ wheat flour

white rice $>$ wheat flour
spaghetti $>$ lentils $>$ kidne

beans $(P<0.001)$

No significant differences between test foods alone and test foods as part of a meal

Mean glucose AUC and peak rise after bean consumption were, respectively, $51 \%(P<0.001)$ and $41 \%(P<0.001)$

$(P<0.01)$ and $45 \%(P<0.001)$

of the values after the bread and

spaghetti; $45 \%(P<0.001)$ and $43 \%$

$(P<0.001)$ of the values after the biscuits;

$51 \%(P<0.001)$ and $48 \%(P<0.001)$ of

the values after the breakfast cereals:

and $55 \%(P<0.01)$ and $45 \%(P<0.001)$

of the values after the tubers
Gl remains discriminating even in the context of population
Leguminous seeds as a est rise in postprandial carbohydrate-rich foods tested 
Table 1. Continued

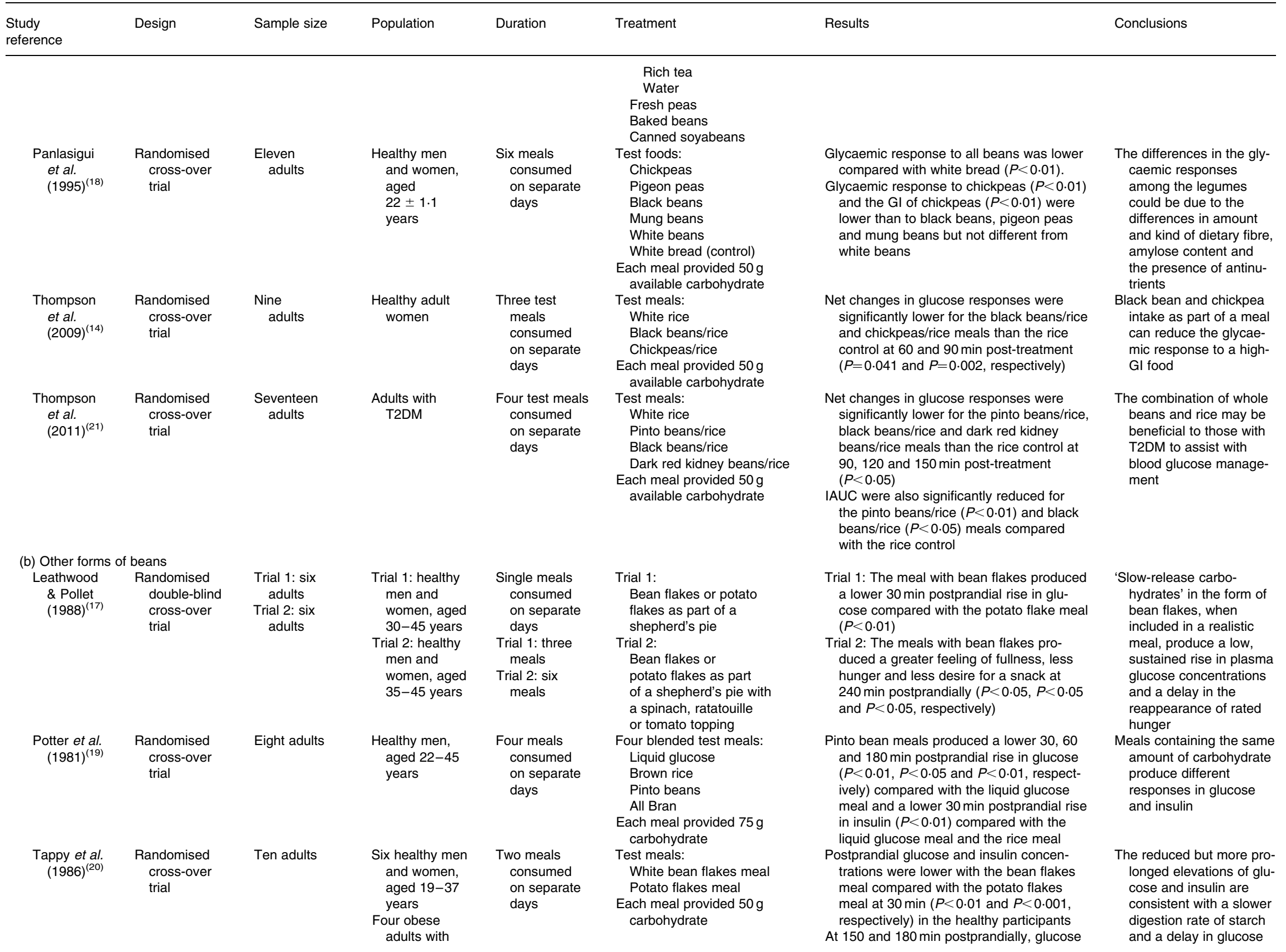




\section{N British Journal of Nutrition}

Table 1. Continued

\begin{tabular}{|c|c|c|c|c|c|c|c|}
\hline $\begin{array}{l}\text { Study } \\
\text { reference }\end{array}$ & Design & Sample size & Population & Duration & Treatment & Results & Conclusions \\
\hline & & & $\begin{array}{l}\text { T2DM, aged } \\
48-61 \text { years }\end{array}$ & & & $\begin{array}{l}\text { ( } P<0.02 \text { and } P<0.05 \text {, respectively) and } \\
\text { insulin concentrations }(P<0.05 \text { and } \\
P<0.05 \text {, respectively) were higher with } \\
\text { the bean flakes meal compared with the } \\
\text { potato flakes meal in the healthy partici- } \\
\text { pants } \\
\text { Statistical analyses were not performed on } \\
\text { the results from the obese diabetic partici- } \\
\text { pants }\end{array}$ & absorption \\
\hline $\begin{array}{l}\text { Torsdottir } \\
\text { et al. } \\
\quad(1989)^{(22)}\end{array}$ & $\begin{array}{l}\text { Randomised } \\
\text { cross-over } \\
\text { trial }\end{array}$ & Six adults & $\begin{array}{l}\text { Healthy men, } \\
\text { aged } 22-30 \\
\text { years }\end{array}$ & $\begin{array}{l}\text { Two test meals } \\
\text { consumed } \\
\text { on separate } \\
\text { days }\end{array}$ & $\begin{array}{l}\text { Test meals: } \\
\text { Mashed bean flakes and } \\
\text { meat } \\
\text { Mashed potato flakes and } \\
\text { meat }\end{array}$ & $\begin{array}{l}\text { Bean flakes meal produced lower blood glu- } \\
\text { cose }(P<0.01) \text { and serum insulin } \\
(P<0.05) \text { concentrations than the potato } \\
\text { flakes meal } \\
\text { IAUC was lower following the bean flakes } \\
\text { meal }(P<0.05) \text { compared with the potato } \\
\text { flakes meal } \\
\text { No significant difference in gastric emptying } \\
\text { between the two meals }\end{array}$ & $\begin{array}{l}\text { Low glycaemic response } \\
\text { after a meal containing } \\
\text { bean flakes may be due } \\
\text { to slow digestion of } \\
\text { bean starch in the small } \\
\text { intestine }\end{array}$ \\
\hline $\begin{array}{l}\text { Tovar et al. } \\
\quad(1992)^{(23)}\end{array}$ & $\begin{array}{l}\text { Randomised } \\
\text { cross-over } \\
\text { trial }\end{array}$ & Ten adults & $\begin{array}{l}\text { Healthy men } \\
\text { and women, } \\
\text { aged } \\
36 \pm 2 \cdot 5 \\
\text { years }\end{array}$ & $\begin{array}{l}\text { Six test meals } \\
\text { consumed } \\
\text { on separate } \\
\text { days }\end{array}$ & $\begin{array}{l}\text { Test meals: } \\
\text { Red beans } \\
\text { Boiled beans } \\
\text { Autoclaved beans } \\
\text { Bean precooked } \\
\text { flour porridge } \\
\text { Bean flour with free } \\
\text { starch cakes } \\
\text { Lentils } \\
\text { Lentil precooked } \\
\text { flour porridge } \\
\text { Wheat bread } \\
\text { Each meal provided } \\
30 \mathrm{~g} \text { available } \\
\text { carbohydrate }\end{array}$ & $\begin{array}{l}\text { All meals containing legumes produced } \\
\text { lower postprandial glucose values at } 30 \\
\text { and } 45 \text { min }(P<0.05) \text { compared with the } \\
\text { wheat bread meal. } \\
\text { All meals containing legumes produced } \\
\text { lower postprandial insulin values at } 30 \\
\text { and } 45 \text { min }(P<0.05) \text { compared with the } \\
\text { wheat bread meal. } \\
\text { Processed bean meals (bean precooked } \\
\text { flour porridge and bean flour with free } \\
\text { starch cakes) produced glucose and insu- } \\
\text { lin responses that were higher than the } \\
\text { whole bean meals but lower than the } \\
\text { wheat bread meals }(P<0.05)\end{array}$ & $\begin{array}{l}\text { Results from this study } \\
\text { confirm the deleterious } \\
\text { effect of processing on } \\
\text { the metabolic responses } \\
\text { to legumes. This may } \\
\text { be attributed in part to } \\
\text { thermal and/or mechan- } \\
\text { ical alteration of the } \\
\text { botanical structure of } \\
\text { the seeds and also to } \\
\text { the release of physically } \\
\text { inaccessible starch by } \\
\text { mechanical disruption of } \\
\text { cell walls }\end{array}$ \\
\hline $\begin{array}{l}\text { Winham } \\
\text { et al. } \\
(2007)^{(8)}\end{array}$ & $\begin{array}{l}\text { Randomised } \\
\text { cross-over } \\
\text { trial }\end{array}$ & $\begin{array}{l}\text { Twelve adults: } \\
\text { low-dose } \\
\text { treatment } \\
\text { Eleven adults: } \\
\text { high-dose } \\
\text { treatment }\end{array}$ & $\begin{array}{l}\text { Healthy men } \\
\text { and women, } \\
\text { aged } 20-65 \\
\text { years }\end{array}$ & $\begin{array}{l}\text { Six test meals } \\
\text { (three low- } \\
\text { dose, three } \\
\text { high-dose) } \\
\text { consumed } \\
\text { on separate } \\
\text { days }\end{array}$ & $\begin{array}{l}\text { Low-dose meals (included } \\
\text { half cup bean paste): } \\
\text { Pinto beans } \\
\text { Black-eyed pea } \\
\text { Navy beans } \\
\text { High-dose meals (included } \\
\text { one cup bean paste): } \\
\text { Pinto beans } \\
\text { Black-eyed pea } \\
\text { Navy beans }\end{array}$ & $\begin{array}{l}\text { No significant differences by dose or bean } \\
\text { type in glucose, insulin response, whole- } \\
\text { body insulin sensitivity or HOMA }\end{array}$ & $\begin{array}{l}\text { When provided in the form } \\
\text { of a spread (bean } \\
\text { paste), pinto bean, navy } \\
\text { bean, or black-eyed pea } \\
\text { intake as part of a treat- } \\
\text { ment did not signifi- } \\
\text { cantly reduce glycaemic } \\
\text { response to high-Gl } \\
\text { foods }\end{array}$ \\
\hline
\end{tabular}

T2DM, type 2 diabetes mellitus; Gl, glycaemic index; AUC, area under the curve; IAUC, incremental area under the curve; HOMA, homeostasis model assessment. 
Table 2. Phaseolus vulgaris species, glycaemic response and type 2 diabetes mellitus and CVD risk

\begin{tabular}{|c|c|c|c|c|c|}
\hline $\begin{array}{l}\text { Study } \\
\text { reference }\end{array}$ & Design & Sample size & Population & Duration & Treatment \\
\hline $\begin{array}{l}\text { Anderson } \\
\text { et al. } \\
(1984)^{(31)}\end{array}$ & $\begin{array}{l}\text { Randomised } \\
\text { parallel } \\
\text { trial }\end{array}$ & $\begin{array}{l}\text { Nine adults on } \\
\text { oat-bran diet } \\
\text { Ten adults on } \\
\text { bean diet }\end{array}$ & $\begin{array}{l}\text { Hypercholestero- } \\
\text { laemic men, } \\
\text { aged 34-66 } \\
\text { years }\end{array}$ & $\begin{array}{l}7 \mathrm{~d} \text { on control } \\
\text { diet fol- } \\
\text { lowed by } \\
21 \mathrm{~d} \text { on test } \\
\text { diet }\end{array}$ & $\begin{array}{l}\text { Oat-bran diet contained } \\
100 \mathrm{~g} \text { oat bran per } \mathrm{d} \\
\text { Bean diet contained } \\
115 \mathrm{~g} \text { dried pinto and } \\
\text { navy beans per } \mathrm{d}\end{array}$ \\
\hline
\end{tabular}

Results

Conclusions

Oat-bran and bean diets both lowered fasting plasma glucose concentrations in hypertriacylglycerolaemic subjects $(P<0.02)$. There was no significan difference between the diets

Oat-bran and bean diets both lowered serum cholesterol levels $(P<0.0005)$ and LDL-cholesterol levels $(P<0.0005$ ) bran and $P<0.0025$ bean). There was no significant difference between the diets

\begin{tabular}{|c|c|c|c|c|c|}
\hline $\begin{array}{l}\text { Bazzano } \\
\text { et al. } \\
(2001)^{(4)}\end{array}$ & Cohort & $\begin{array}{l}9632 \text { adults } \\
\text { Cases: } \\
1802 \mathrm{CHD} \\
\text { and } 3680 \\
\text { CVD }\end{array}$ & $\begin{array}{l}\text { Men and women } \\
\text { who participated } \\
\text { in the First } \\
\text { National Health } \\
\text { and Nutrition } \\
\text { examination } \\
\text { Survey Epide- } \\
\text { miologic Follow- } \\
\text { up Study with no } \\
\text { CVD at baseline }\end{array}$ & $\begin{array}{c}\text { Average } 19 \\
\text { years of } \\
\text { follow-up }\end{array}$ & $\begin{array}{l}\text { None; frequency of } \\
\text { legume intake was } \\
\text { estimated using a } \\
\text { 3-month FFQ }\end{array}$ \\
\hline $\begin{array}{l}\text { Cobiac } \\
\text { et al. } \\
\quad(1990)^{(32)}\end{array}$ & $\begin{array}{l}\text { Randomised } \\
\text { cross-over } \\
\text { trial }\end{array}$ & $\begin{array}{l}\text { Twenty } \\
\text { adults }\end{array}$ & $\begin{array}{l}\text { Mildly hypercholes- } \\
\text { terolaemic men, } \\
\text { aged } \\
29-65 \text { years }\end{array}$ & $\begin{array}{l}4 \text { weeks per } \\
\text { interven- } \\
\text { tion }\end{array}$ & $\begin{array}{l}\text { Low-fibre diet with one } \\
\text { meal replaced by: } \\
440 \mathrm{~g} \text { canned baked } \\
\text { beans daily } \\
\text { or } \\
440 \mathrm{~g} \text { canned spaghetti } \\
\text { daily }\end{array}$ \\
\hline $\begin{array}{l}\text { Fleming \& } \\
\text { Shaheen } \\
(1988)^{(33)}\end{array}$ & $\begin{array}{l}\text { Randomised } \\
\text { cross-over } \\
\text { trial }\end{array}$ & Six adults & $\begin{array}{l}\text { Healthy men, aged } \\
21-32 \text { years }\end{array}$ & $\begin{array}{l}8 \mathrm{~d} \text { per } \\
\text { interven- } \\
\text { tion }\end{array}$ & $\begin{array}{l}\text { Controlled diet with: } \\
\text { Dark red kidney beans } \\
\text { daily } \\
\text { or } \\
\text { Bran cereal daily } \\
\text { Total weight of food } \\
\text { provided in proportion } \\
\text { to body weight }\end{array}$ \\
\hline $\begin{array}{l}\text { Jang } \\
\quad \text { et al. } \\
\quad(2001)^{(34)}\end{array}$ & $\begin{array}{l}\text { Randomised } \\
\text { parallel } \\
\text { controlled } \\
\text { trial }\end{array}$ & $\begin{array}{l}\text { Seventy-six } \\
\text { adults }\end{array}$ & $\begin{array}{l}\text { Hypercholestero- } \\
\text { laemic and/or } \\
\text { hypertriacylgly- } \\
\text { cerolaemic men, } \\
\text { aged } \\
58 \cdot 4 \pm 1.53 \\
\text { (control) and } \\
54 \cdot 8 \pm 1 \cdot 20 \\
\text { (whole grain/ } \\
\text { legume) years }\end{array}$ & $\begin{array}{l}\text { 4-week run- } \\
\text { in on usual } \\
\text { diet } \\
\text { 16-week } \\
\text { interven- } \\
\text { tion }\end{array}$ & $\begin{array}{l}\text { Control diet: usual diet } \\
\text { containing cooked } \\
\text { refined rice } \\
\text { Intervention diet: } 70 \mathrm{~g} \\
\text { whole grain/legume } \\
\text { powder ( } 22.2 \% \text { black } \\
\text { beans) replacing } \\
\text { cooked refined rice } \\
\text { for breakfast daily }\end{array}$ \\
\hline
\end{tabular}

Legume consumption inversely associated with risk of $\mathrm{CHD}(P=0.002$ for trend) and CVD $(P=0.02$ for trend) after adjustment for established CVD risk factors

Consuming legumes four or more times each week compared with less than one time per week associated with $22 \%$ lower risk of $\mathrm{CHD}(\mathrm{RR}=0.78 ; 95 \% \mathrm{Cl} 0.68$ $0.90)$ and $11 \%$ lower risk of CVD (RR $=0.89,95 \% \mathrm{Cl} 0.80,0.98)$

Neither the baked bean nor spaghetti treatment significantly altered total, HDL- or LDL-cholesterol, TAG or glucose concentrations

Insulin responses on days 1 and 7 were lower following bean consumption $(P \leq 0.02)$

Glucose and insulin responses were both lower on day 7 compared with day 1 following both bean and bran cerea consumption $(P \leq 0.05)$

The postprandial insulin concentrations following lunch were higher after consumption of the bean breakfast $(P=0.03)$

HDL-cholesterol concentrations increased with the whole grain/

legume powder intervention $(P=0.001)$

Glucose, malondialdehyde,

8-epi-PGF ${ }_{2 \alpha}$, and homocysteine concentrations decreased with the whole grain/legume powder intervention $(P=0.000, P=0.028, P=0.003$ and $P=0.032$, respectively)

OGTT revealed nine subjects in the contro group and twelve subjects in the whole grain/legume powder group had
Oat-bran and bean diets had a favourable impact on total and hypercholesterolaemic men

Oat-bran and bean diets lowered fasting plasma glucose concentrations However, this study did not explor However, this study did not explore the improvement in centrations and the hypocholesterolaemic effect of the diets

Legume intake, estimated using an FFQ, is inversely related to risk

This study did not address the role that legumes influence on glycaemic response might play in the $\mathrm{CHD}$ and $\mathrm{CVD}$ risk reduction

This study found that baked bean consumption did not have an impact on risk factors for CVD or T2DM

The study did not assess the impact of glycaemic response

on total, HDL- or LDL-cholesterol concentrations

Consumption of a high-fibre breakfast containing either dark red kidney beans or bran cereal reduced postprandial insulin and glucose responses after $7 d$

Consumption of dark red kidney beans reduced postprandial insulin after breakfast, but increased postprandial insulin after lunch

The study did not assess the impact of glycaemic response on long-term risk for chronic disease

Consumption of a whole grain/legume powder reduced multiple risk factors for chronic disease and increased HDL-cholesterol concentrations

The study did not assess whether the impact of the whole grain/ legume powder on glycaemic response influenced the other risk factor modifications reported 


\section{N British Journal of Nutrition}

Table 2. Continued

\begin{tabular}{|c|c|c|c|c|c|c|c|}
\hline $\begin{array}{l}\text { Study } \\
\text { reference }\end{array}$ & Design & Sample size & Population & Duration & Treatment & Results & Conclusions \\
\hline & & & & & & $\begin{array}{l}\text { new-onset T2DM } \\
\text { In non-diabetic subjects, whole grain/ } \\
\text { legume powder consumption decreased } \\
\text { fasting glucose, response areas of glu- } \\
\text { cose and insulin during OGTT, and insulin } \\
\text { resistance } \\
\text { In the T2DM subjects, whole grain/ } \\
\text { legume powder consumption decreased } \\
\text { fasting glucose and the response area of } \\
\text { glucose during OGTT }\end{array}$ & \\
\hline $\begin{array}{l}\text { McAuley } \\
\text { et al. } \\
(2002)^{(104)}\end{array}$ & $\begin{array}{l}\text { Randomised } \\
\text { parallel } \\
\text { trial }\end{array}$ & $\begin{array}{l}\text { Seventy-nine } \\
\text { adults }\end{array}$ & $\begin{array}{l}\text { Normoglycaemic } \\
\text { insulin-resistant } \\
\text { men and women }\end{array}$ & 4 months & $\begin{array}{l}\text { Modest diet and exercise } \\
\text { programme } \\
\text { Intensive diet and } \\
\text { exercise programme } \\
\text { (included recommen- } \\
\text { dation for legume } \\
\text { consumption) } \\
\text { Control group }\end{array}$ & $\begin{array}{l}\text { Intensive diet and exercise programme } \\
\text { group improved insulin sensitivity ( } 25 \% \\
\text { increase, } P=0.006 \text { v. } 9 \% \text { in the modest } \\
\text { group, } P=0.23)\end{array}$ & $\begin{array}{l}\text { This study indicated that intensive } \\
\text { diet and exercise therapy may be } \\
\text { required to improve insulin sensi- } \\
\text { tivity in insulin-resistant adults } \\
\text { Legumes were recommended as part } \\
\text { of the intensive diet and exercise } \\
\text { programme, but this study did not } \\
\text { directly address the influence of the } \\
\text { legumes on glycaemic response } \\
\text { and how that may have altered } \\
\text { insulin sensitivity }\end{array}$ \\
\hline $\begin{array}{l}\text { Winham } \\
\text { et al. } \\
(2007)^{(36)}\end{array}$ & $\begin{array}{l}\text { Randomised } \\
\text { cross-over } \\
\text { controlled } \\
\text { trial }\end{array}$ & $\begin{array}{l}\text { Sixteen } \\
\text { adults }\end{array}$ & $\begin{array}{l}\text { Hyperinsulinaemic } \\
\text { men }(n 7) \text { and } \\
\text { women }(n 9) \\
\text { aged } 22-65 \\
\text { years }\end{array}$ & $\begin{array}{l}8 \text { weeks per } \\
\text { interven- } \\
\text { tion }\end{array}$ & $\begin{array}{l}\text { Control: } \\
\text { Half cup canned } \\
\text { carrots daily } \\
\text { Interventions: } \\
\text { Half cup canned pinto } \\
\text { beans daily } \\
\text { Half cup canned } \\
\text { black-eyed peas } \\
\text { daily }\end{array}$ & $\begin{array}{l}\text { Consumption of half cup pinto beans } \\
\text { decreased total and LDL-cholesterol } \\
\text { concentrations }(P=0.011 \text { and } P=0.013 \text {, } \\
\text { respectively) } \\
\text { HDL-cholesterol, TAG, hs-CRP, glucose, } \\
\text { insulin and } \mathrm{HbA} \mathrm{H}_{1 \mathrm{c}} \text { were not significantly } \\
\text { different }\end{array}$ & $\begin{array}{l}\text { Daily pinto bean consumption } \\
\text { decreased total and LDL-choles- } \\
\text { terol concentrations in this study } \\
\text { Since glucose, insulin and } \mathrm{HbA}_{1 \mathrm{c}} \\
\text { values were not significantly } \\
\text { altered, this study does not indicate } \\
\text { that the influence of beans on } \\
\text { glycaemic response was related } \\
\text { to the change in cholesterol } \\
\text { concentrations }\end{array}$ \\
\hline $\begin{array}{l}\text { Winham \& } \\
\text { Hutchins } \\
(2007)^{(35)}\end{array}$ & $\begin{array}{l}\text { Randomised } \\
\text { cross-over } \\
\text { controlled } \\
\text { trial }\end{array}$ & $\begin{array}{l}\text { Twenty-three } \\
\text { adults }\end{array}$ & $\begin{array}{l}\text { Hypercholestero- } \\
\text { laemic men } \\
(n 10) \text { and } \\
\text { women }(n 13) \\
\text { aged } 22-70 \\
\text { years }\end{array}$ & $\begin{array}{l}8 \text { weeks per } \\
\text { interven- } \\
\text { tion }\end{array}$ & $\begin{array}{l}\text { Control: half cup canned } \\
\text { carrots daily } \\
\text { Intervention: half cup } \\
\text { vegetarian baked } \\
\text { beans daily }\end{array}$ & $\begin{array}{l}\text { Consumption of half cup baked beans } \\
\text { decreased total cholesterol concen- } \\
\text { trations }(P=0.01) \\
\text { LDL-cholesterol, HDL-cholesterol, TAG, } \\
\text { hs-CRP, glucose, insulin and } \mathrm{HbA}_{1 \mathrm{c}} \text { were } \\
\text { not significantly different }\end{array}$ & $\begin{array}{l}\text { Daily baked bean consumption } \\
\text { decreased total cholesterol } \\
\text { concentrations in this study } \\
\text { Since glucose, insulin and } \mathrm{HbA}_{1 \mathrm{c}} \\
\text { values were not significantly } \\
\text { altered, this study does not indicate } \\
\text { that the influence of beans on } \\
\text { glycaemic response was related } \\
\text { to the change in cholesterol } \\
\text { concentrations }\end{array}$ \\
\hline $\begin{array}{l}\text { Wursch } \\
\text { et al. } \\
\quad(1988)^{(37)}\end{array}$ & $\begin{array}{l}\text { Randomised } \\
\text { cross-over } \\
\text { controlled } \\
\text { trial }\end{array}$ & Six adults & $\begin{array}{l}\text { Healthy young } \\
\text { men, aged } \\
26 \pm 6 \text { years }\end{array}$ & $\begin{array}{l}7 \mathrm{~d} \text { per test } \\
\text { meal } \\
\text { (breakfast) }\end{array}$ & $\begin{array}{l}\text { Control: } 58 \mathrm{~g} \text { glucose in } \\
150 \mathrm{ml} \text { water } \\
\text { Test meals (breakfast): } \\
114 \mathrm{~g} \text { white kidney } \\
\text { bean flakes daily } \\
\text { or } \\
62 \mathrm{~g} \text { potato flakes, } 38.5 \mathrm{~g} \\
\text { low-starch wheat bran } \\
\text { and } 17 \mathrm{~g} \text { soya isolate } \\
\text { daily }\end{array}$ & $\begin{array}{l}\text { Mean area under the glucose response } \\
\text { curve at } 1 \text { and } 2 \mathrm{~h} \text { was higher following } \\
\text { the potato flake-based test meal com- } \\
\text { pared with the bean flake test meal } \\
(P<0.01 \text { and } P<0.05 \text {, respectively) } \\
\text { Mean area under the insulin response curve } \\
\text { at } 1,2 \text { and } 6 \mathrm{~h} \text { was higher following the } \\
\text { potato flake-based test meal compared } \\
\text { with the bean flake test meal }(P<0.01 \text {, } \\
P<0.01 \text { and } P<0.02 \text {, } \\
\text { respectively) }\end{array}$ & $\begin{array}{l}\text { A breakfast containing bean flakes } \\
\text { favourably altered postprandial glu- } \\
\text { cose and insulin response curves } \\
\text { Since this was a short-term study, } \\
\text { the influence of the favourable } \\
\text { postprandial effects of bean flakes } \\
\text { on risk for chronic disease was } \\
\text { not assessed }\end{array}$ \\
\hline
\end{tabular}

RR, relative risk; T2DM, type 2 diabetes mellitus; OGTT, oral glucose tolerance test; hs-CRP, high-sensitivity C-reactive protein. 
glycaemic response when consumed. Studies that explore how beans exert their influence on T2DM prevention and treatment and whether their effect on glycaemic response is related to that influence are required.

\section{Impact of Phaseolus vulgaris species and glycaemic response on CVD and CVD risk factors}

Besides controlling postprandial glucose increases, numerous research studies indicate that a low-GI diet may also play a role in reducing the risk for or preventing CVD; however, these studies did not focus on beans as a low-GI food. These studies have been analysed and summarised elsewhere $^{(25,26,38-40)}$ and so will not be covered in detail in the present review. Despite the interest in the role of a low-GI diet in CVD risk reduction, the mechanisms behind this risk reduction have yet to be determined. A Cochrane review examined twenty-one randomised controlled trials that included a total of 713 participants. This review found no evidence that low-GI diets influenced changes in certain well-known risk factors for CVD including HDL-cholesterol, LDL-cholesterol, TAG or total cholesterol concentrations. The authors of the Cochrane review reported that many of the trials included in the review were 'short-term, of poor quality and did not have sufficient power to detect clinical important differences, ${ }^{\text {, }} 41$.

Observational studies and a very limited number of randomised controlled trials indicate a beneficial effect of bean consumption on short-term satiety and weight loss when combined with energy restriction ${ }^{(42,43)}$, but these effects may not be related to the relationship between bean intake and glycaemic response. Few studies isolated and examined $P$. vulgaris species intake separately from other food groups $^{(42,43)}$, and none of these studies directly addressed the relationship between bean intake, glycaemic response and short-term satiety and weight loss, so results in this area should be interpreted with caution.

Although $P$. vulgaris species are known to decrease LDL-cholesterol, a well-known risk factor for CVD, in normocholesterolaemic and hypercholesterolaemic participants ${ }^{(35,36,44-47)}$, this effect is most probably attributed to the soluble fibre found in the beans and not to the impact the beans have on glycaemic response. Nevertheless, other risk factors for CVD, such as oxidative stress, have been identified and low-GI foods such as beans and low-GI diets may favourably influence these risk factors.

In addition to chronic hyperglycaemia, elevated postprandial glucose can increase oxidative stress, worsen endothelium-dependent vasodilation and raise blood pressure $^{(10,48-50)}$. Dysmetabolic changes after eating are significant contributors to CVD risk and individuals with T2DM are already at increased risk of CVD. On the other hand, controlling the postprandial glucose response by the inclusion of low-GI/GL foods in the diet can decrease CVD risk. Dietary patterns that include low-GI/GL foods, such as beans, were associated with a lower risk for CVD, even after accounting for other known risk factors such as cigarette smoking, obesity and family history in a prospective cohort study of 44875 men aged $40-75$ years ${ }^{(51)}$.

\section{Impact of Phaseolus vulgaris species and glycaemic response on cancer and cancer risk factors}

Researchers hypothesise that glycaemic response may increase cancer risk through the modulation of hormone concentrations (for example, insulin-like growth factor) by insulin and that hyperinsulinaemia may increase cancer risk $^{(52,53)}$. Studies examining the effect of GI and GL on the risk for various cancers (breast, colorectal, endometrial, gastric, ovarian, pancreatic, prostate, renal) report mixed results ${ }^{(54-81)}$ Most studies utilised either a cohort or case-control design, relying on FFQ to determine the average daily GI and GL of participants ${ }^{(54-59,61-64,67-70,74-81)}$. Inaccurate memory of foods consumed over the recall period (typically $1-2$ years) and recall bias are potential confounding factors with FFQ and retrospective studies in general. Researchers also acknowledge that the reliability and validity of estimating average daily GI and GL from FFQ is questionable. Some GI and GL values have been obtained from small samples and the variability of the values is undetermined ${ }^{(54-58)}$.

Few studies have reported the relationship of $P$. vulgaris species and glycaemic response on cancer risk (Table 3) $(59,66,74)$. We were unable to find any studies that had the examination of bean intake, glycaemic response and cancer risk or incidence as a primary objective. One cohort and one case-control study found weak associations between legume intake and a reduction in cancer risk related to a decrease in glycaemic response ${ }^{(59,74)}$. A randomised controlled trial found that a high-legume diet and a healthy American diet both favourably influenced biomarkers for cancer risk ${ }^{(66)}$. If the hypothesis that glycaemic response makes an impact on cancer risk via insulin actions and interactions, then incorporation of beans into the diet to modulate the glycaemic response could have a favourable impact on the risk for a variety of cancers. However, determining the impact of glycaemic response and beans on cancer risk in a human population will require more accurate and reliable methods of tracking diet intake over long periods of time.

\section{Composition of Phaseolus vulgaris species of beans}

According to the Dietary Guidelines for Americans and the United States Department of Agriculture, beans are classified as both a protein and a starchy vegetable source ${ }^{(82)}$. Beans contain a high amount of protein, with one serving of most bean types (half cup) providing 7-8g. Beans are also an excellent source of fibre, providing 3-9 g of soluble and insoluble fibre per half-cup serving ${ }^{(83)}$.

Beans contain very little fat, generally accounting for less than $3 \%$ of the energy content, and have a very low saturated fat content ${ }^{(84)}$. Beans are also high in folate, Fe, $\mathrm{Mg}, \mathrm{Zn}, n-3$ fatty acids and antioxidants ${ }^{(7,85-88)}$. They contain phytate and phenolic compounds that may function similarly to glucose-lowering $\alpha$-glucosidase or $\alpha$-amylase inhibitor T2DM medications such as metformin and acarbose ${ }^{(7,86)}$. 
Table 3. Phaseolus vulgaris species, glycaemic response and cancer risk

\begin{tabular}{|c|c|c|c|c|c|c|c|}
\hline $\begin{array}{l}\text { Study refer- } \\
\text { ence }\end{array}$ & Design & Sample size & Population & Duration & Treatment & Results & Conclusions \\
\hline $\begin{array}{l}\text { Cho } \\
\text { et al. } \\
(2003)^{(59)}\end{array}$ & Cohort & $\begin{array}{l}714 \text { cases of breast } \\
\text { cancer from popu- } \\
\text { lation of } 90655 \\
\text { over } \\
8 \text { years follow-up }\end{array}$ & $\begin{array}{c}\text { Premenopausal } \\
\text { women, aged } \\
26-46 \text { years }\end{array}$ & $\begin{array}{l}\text { Cases identified } \\
\text { between } 1991 \\
\text { and } 1999\end{array}$ & $\begin{array}{l}\text { None; semi-quantitative } \\
\text { FFQ with } 133 \text { food } \\
\text { items (initial) and } 142 \\
\text { food items (follow-up) } \\
\text { used to calculate Gl } \\
\text { and GL }\end{array}$ & $\begin{array}{l}\text { GI and GL were not associated with } \\
\text { breast cancer risk. There was a } \\
\text { weak, non-significant inverse } \\
\text { association between intake of } \\
\text { fibre from legumes and breast } \\
\text { cancer risk (RR } \\
\text { for } 5 \text { th quintile compared with } 1 \text { st } \\
\text { quintile }=0.79 ; 95 \% \mathrm{Cl} 0.62, \\
1.02 ; P \text { for trend }=0.04 \text { ) }\end{array}$ & $\begin{array}{l}\text { This study did not find a relationship } \\
\text { between Gl and GL and breast cancer } \\
\text { risk } \\
\text { Although there was a weak, non-signifi- } \\
\text { cant inverse association between } \\
\text { intake of fibre from legumes and } \\
\text { breast cancer risk, there is no evi- } \\
\text { dence that the relationship between } \\
\text { legumes and glycaemic response is } \\
\text { related to this association }\end{array}$ \\
\hline $\begin{array}{l}\text { Hartman } \\
\text { et al. } \\
\quad(2010)^{(66)}\end{array}$ & $\begin{array}{l}\text { Randomised } \\
\text { controlled } \\
\text { trial }\end{array}$ & Sixty-four men & $\begin{array}{l}\text { Men, aged } 35-75 \\
\text { years, without a } \\
\text { history of color- } \\
\text { ectal cancer }\end{array}$ & $\begin{array}{l}4 \text { weeks on } \\
\text { each diet }\end{array}$ & $\begin{array}{l}\text { Control diet (high-GI (69) } \\
\text { healthy } \\
\text { American diet) } \\
\text { High-legume }(250 \mathrm{~g} / \mathrm{d}) \text {, } \\
\text { low-Gl } \\
\text { (38) diet }\end{array}$ & $\begin{array}{l}\text { Both diets significantly reduced fast- } \\
\text { ing CRP }(P=0.018 \text { legume and } \\
P=0.007 \text { control) and sTNFRI } \\
(P=0.005 \text { legume and } P=0.001 \\
\text { control). The control diet signifi- } \\
\text { cantly reduced sTNRFII } \\
(P<0.001) \\
\text { Neither diet decreased fasting insu- } \\
\text { lin or C-peptide concentrations. } \\
\text { The control diet reduced the fast- } \\
\text { ing glucose concentration } \\
(P=0.012) \text { and the legume diet } \\
\text { increased it }(P=0.001)\end{array}$ & $\begin{array}{l}\text { Both the control and high-legume diets } \\
\text { had favourable effects on biomarkers } \\
\text { associated with incidence of colorectal } \\
\text { cancer and adenomas } \\
\text { In this study, the legume diet increased } \\
\text { fasting glucose concentrations, a } \\
\text { result that is inconsistent with the typi- } \\
\text { cal reported influence of legumes on } \\
\text { glycaemic response }\end{array}$ \\
\hline $\begin{array}{l}\text { Potischman } \\
\text { et al. } \\
(1999)^{(74)}\end{array}$ & $\begin{array}{l}\text { Case- } \\
\text { control }\end{array}$ & $\begin{array}{l}568 \text { cases; } 1451 \\
\text { controls }\end{array}$ & $\begin{array}{l}\text { Cases: Premeno- } \\
\text { pausal women, } \\
\text { aged } 20-44 \\
\text { years, with } \\
\text { breast cancer } \\
\text { Controls: Preme- } \\
\text { nopausal } \\
\text { women, aged } \\
20-44 \text { years, } \\
\text { without cancer }\end{array}$ & $\begin{array}{l}\text { Cases identified } \\
\text { between } 1990 \\
\text { and } 1992\end{array}$ & $\begin{array}{l}\text { None; modified version } \\
\text { of standard 100-item } \\
\text { NCI-Block FFQ }\end{array}$ & $\begin{array}{l}\text { Increased intake of beans (OR } 0.87 \\
95 \% \mathrm{Cl} 0.7,1 \cdot 2 ; 4 \text { th quartile) and } \\
\text { fibre from beans (OR } 0.88 ; 95 \% \\
\mathrm{Cl} 0.7,1 \cdot 24 \text { th quartile) were } \\
\text { associated with reduced breast } \\
\text { cancer risk }\end{array}$ & $\begin{array}{l}\text { Increased bean intake is associated with } \\
\text { a minimal, if any, reduction in risk of } \\
\text { early-stage breast cancer among } \\
\text { young women. } \\
\text { Although there was a small reduction in } \\
\text { risk of early-stage breast cancer } \\
\text { among young women associated with } \\
\text { bean and bean fibre intake, there is } \\
\text { no evidence that the relationship } \\
\text { between beans and glycaemic } \\
\text { response is related to this association }\end{array}$ \\
\hline
\end{tabular}

Gl, glycaemic index; GL, glycaemic load; RR, relative risk; CRP, C-reactive protein; sTNFRI/II, soluble tumour necrosis factor- $\alpha$ receptors I and II; NCI, National Cancer Institute. 
The predominant macronutrient in beans is carbohydrate, contributing $60-65 \%$ of the energy content. Starch, the primary digestible carbohydrate in beans, can be categorised as readily digestible, slowly digestible and resistant $\operatorname{starch}^{(89)}$. All bean varieties including the $P$. vulgaris species contain a higher ratio of slowly digestible:readily digestible starch compared with other starchy foods. In general, most beans contain 30-40\% amylose, a linear polymer of glucose units ( $\alpha 1-4$ linkages), whereas most other starches contain $20-30 \%$ amylose. Starches with more than $30 \%$ amylose are readily digestible or resistant starch depending on the amylose content and hydrothermal treatment applied to the food. Beans also contain a substantial amount of resistant starch, considered as a dietary fibre. Resistant starch is defined as any starch that resists digestion by amylase in the small intestine and progresses to the large intestine for fermentation by the gut bacteria ${ }^{(90,91)}$. Slowly digestible starch is associated with reduced glycaemic responses and lower postprandial glucose levels compared with readily digestible starch. This attenuated glycaemic response can benefit both insulinresistant individuals and individuals with diabetes.

\section{Proposed mechanisms of action}

The mechanism of action responsible for the low glycaemic response to beans is multifaceted. Possible explanations include a high content of viscous fibre, protein, relatively high amylose starch and antinutrients. In addition, processing methods affecting the physical form of the beans may alter their glycaemic response.

Beans are commonly consumed in their whole form, or as a minimally processed food with little or no grinding. Eating the intact bean maintains the integrity of the cell wall, slowing digestion of the bean in the upper small intestine. Whole beans also have cell walls that are more resistant to digestion than the cell walls of cereal grains. Minimal or no processing of the bean combined with the resistance of the bean cell wall to digestion provides a likely primary mechanism of action that explains the low glycaemic response to beans ${ }^{(92)}$.

Viscous fibres form a gel-like substance along the digestive tract, which may slow the rate of gastric emptying and absorption rate of nutrients. Inclusion of a viscous fibre with a test meal may reduce the blood glucose response by an average of $44 \%{ }^{(93)}$. Purified viscous fibres also reduce postprandial gastric inhibitory polypeptide and insulin levels more effectively than non-viscous fibres ${ }^{(94,95)}$. Beans are particularly high in soluble fibres that increase viscosity of the intestinal lumen or the unstirred water layer ${ }^{(96-98)}$. However, Tappy et $a{ }^{(20)}$ found significantly lower glucose and insulin responses to a bean meal alone compared with a potato meal with added bean fibre. Therefore, the attenuated glycaemic response seen as a result of bean consumption cannot be explained solely by the beans' fibre content

The protein fraction of beans may interact with starch to reduce the digestibility and glycaemic response of that starch. Alli \& Baker ${ }^{(99)}$ found carbohydrates tightly bound to proteins isolated from uncooked beans using citric acid and sodium hydroxide extracts, providing evidence for a starch-protein interaction.

The ratio of amylose:amylopectin starch found in beans may also alter the glycaemic response. The higher molecular weight, greater surface area and branching structure of amylopectin make it subject to faster digestion than amylose. High-amylose meals (70\% amylose) compared with highamylopectin meals (70\% amylopectin) result in significantly lower plasma glucose in healthy normoglycaemic adults at 30 and $60 \mathrm{~min}$ after meal consumption ${ }^{(100)}$. Among natural sources of carbohydrates, beans have the highest percentage of starch as amylose (30-40\%), which is 5-10\% more amylose than is found in most cereals ${ }^{(90)}$.

In addition to protein-starch interactions and the nature of the starch in beans, the phytic acid content of beans may influence the glycaemic response after bean consumption. The phytic acid content of beans is high compared with non-bean foods. There is a negative correlation between phytic acid concentrations and glycaemic indices for non-diabetic adults $(r-0.78, P<0 \cdot 001)^{(101)}$. A study using unleavened bread made from navy bean flour (containing phytic acid) demonstrated that consuming the navy bean bread significantly reduced blood glucose area under the curve by $64 \%$ compared with that of unleavened bread made from white wheat flour ${ }^{(102)}$. Removing the phytic acid from the navy bean flour significantly increased the glycaemic area under the curve by $141 \%$. Phytic acid is believed to inhibit starch digestion both directly and indirectly. Structurally, phytic acid binds directly with starch through phosphate bonds and reduces starch digestibility ${ }^{(102)}$. Indirectly, phytic acid may bind to cations such as Ca. Since the stability of $\alpha$-amylases, including pancreatic $\alpha$-amylase, is dependent on $\mathrm{Ca}^{(101)}$, the lack of available $\mathrm{Ca}$ can decrease the effectiveness of $\alpha$-amylases, slowing the rate of starch digestion. Phytic acid also binds to negatively charged groups on proteins, such as $\alpha$-amylases, at neutral and alkaline $\mathrm{pH}^{(102)}$, rendering them useless and reducing the digestion of starch by amylase.

\section{Future directions}

All beans are not created equal - nor do they elicit identical biological responses when consumed. Even though the GI values for beans are typically very low, studies examining the glycaemic effects of assorted beans from $P$. vulgaris species have demonstrated that the glycaemic response differs based on the bean used. Researchers should continue to study different beans from the $P$. vulgaris species to determine the individual glycaemic effects associated with each bean type.

Definitively determining if the form of the bean consumed changes the glycaemic response, or other positive biological effects associated with bean consumption, should be a priority. As interest in the P. vulgaris species increases, the food industry will probably formulate functional or manufactured foods that contain ground beans, bean powder, bean paste, etc. to address the marketing potential in this area. Research is needed to ensure that the various forms in which the bean can be utilised impart the same beneficial 
properties associated with the consumption of whole beans, including maintaining the low-GI/GL qualities.

Studies such as the one conducted by Kallio et al. ${ }^{(103)}$ demonstrate that foods can make an impact and act via molecular pathways by affecting signal transduction and gene function. The constituents of foods that act on these pathways go beyond the traditional macro- and micronutrient content typically reported for such foods. Research that identifies the phytochemical components of foods, including beans, is desperately needed to allow research in this area to progress. We are just beginning to explore the mechanisms of action that are responsible for the chronic disease risk-reduction benefits conferred by whole bean consumption. More research is required to define the pathways involved, including those related to changes in oxidative stress, endothelium-dependent vasodilation, and blood pressure, in order to determine the full extent of the influence that beans have on the prevention of chronic disease.

\section{Summary}

Traditional foods such as beans should be retained in the diet because of their many health benefits, including a positive impact on postprandial glycaemic response. Hyperglycaemia, whether it occurs following a meal or due to poorly controlled T2DM, is known to increase oxidative stress, contribute to hypertension and increase the risk for CVD. Examination of the glycaemic response to meals, especially culturally important food combinations such as beans and rice, is important for the prevention and control of hyperglycaemia-induced diseases.

Understanding the glycaemic responses elicited by the beans of the $P$. vulgaris market classification and how these responses vary depending on the bean consumed is essential. Since not all beans are equal in response, these findings will allow provision of accurate nutrition education to individuals who have, or are at risk for, T2DM.

\section{Acknowledgements}

The preparation of the present review article received no specific grant funding from any funding agency in the public, commercial or not-for-profit sectors. A. M. H. and S. V. T. were responsible for retrieving references. A. M. H. and D. M. W. were responsible for writing the article. S. V. T. was responsible for the design of the tables. A. M. H., S. V. T. and D. M. W. were responsible for critical reading and evaluation, presentation of the data and article editing. The article has been read and approved by all authors. A. M. H. and D. M. W. have previously received research funding from Bush Brothers \& Company and the US Dry Bean Council. A. M. H. is a member of the editorial advisory board for the Dry Bean Quarterly, published by the Northarvest Bean Growers Association, serves as an editor for Bean Briefs, published by the US Dry Bean Council, and has written a white paper supporting the promotion of bean consumption for the US Dry Bean Council. D. M. W. has served as a research advisor for Bush Brothers \& Company and Pulse Canada.
S. V. T. has no conflicts of interest to report related to the content of the present review article.

\section{References}

1. Ceriello A (2008) Cardiovascular effects of acute hyperglycaemia: pathophysiological underpinnings. Diab Vasc Dis Res 5, 260-268.

2. Ceriello A (2008) Possible role of oxidative stress in the pathogenesis of hypertension. Diabetes Care 31, Suppl. 2, S181-S184.

3. Ceriello A, Esposito K, Piconi L, et al. (2008) Oscillating glucose is more deleterious to endothelial function and oxidative stress than mean glucose in normal and type 2 diabetic patients. Diabetes 57, 1349-1354.

4. Bazzano LA, He J, Ogden LG, et al. (2001) Legume consumption and risk of coronary heart disease in US men and women: NHANES I Epidemiologic Follow-up Study. Arch Intern Med 161, 2573-2578.

5. Darmadi-Blackberry I, Wahlqvist ML, Kouris-Blazos A, et al. (2004) Legumes: the most important dietary predictor of survival in older people of different ethnicities. Asia Pacific J Clin Nutr 13, 217-220.

6. Esposito K, Ciotola M, Giugliano F, et al. (2006) Mediterranean diet improves erectile function in subjects with metabolic syndrome. Int J Impotence Res 18, 405-410.

7. Sievenpiper JL, Kendall CW, Esfahani A, et al. (2009) Effect of non-oil-seed pulses on glycaemic control: a systematic review and meta-analysis of randomised controlled experimental trials in people with and without diabetes. Diabetologia 52, 1479-1495.

8. Winham DM, Hutchins AM \& Melde CL (2007) Pinto bean, navy bean, and black-eye pea consumption do not significantly lower the glycemic response to a high glycemic index treatment in normoglycemic adults. Nutr Res 27, $535-541$

9. Atkinson FS, Foster-Powell K \& Brand-Miller JC (2008) International tables of glycemic index and glycemic load values: 2008. Diabetes Care 31, 2281-2283.

10. O'Keefe JH \& Bell DSH (2007) Postprandial hyperglycemia/ hyperlipidemia (postprandial dysmetabolism) is a cardiovascular risk factor. Am J Cardiol 100, 899-904.

11. Lavi T, Karasik A, Koren-Morag N, et al. (2009) The acute effect of various glycemic index dietary carbohydrates on endothelial function in nondiabetic overweight and obese subjects. J Am Coll Cardiol 53, 2283-2287.

12. Foster-Powell K, Holt SHA \& Brand-Miller JC (2002) International table of glycemic index load values: 2002. Am J Clin Nutr 76, 5-58.

13. Bornet FR, Costagliola D, Rizkalla SW, et al. (1987) Insulinemic and glycemic indexes of six starch-rich foods taken alone and in a mixed meal by type 2 diabetics. Am J Clin Nutr 45, 588-595.

14. Thompson SV, Winham DM \& Hutchins AM (2009) Black bean and chickpea consumption reduce glycemic response as part of a rice meal. FASEB J 23, 540-542.

15. Sheard NF, Clark NG, Brand-Miller JC, et al. (2004) Dietary carbohydrate (amount and type) in the prevention and management of diabetes. Diabetes Care 27, 2266-2271.

16. Jenkins DJ, Wolever TM, Taylor RH, et al. (1980) Exceptionally low blood glucose response to dried beans: comparison with other carbohydrate foods. Br Med J 281, $578-580$ 
17. Leathwood P \& Pollet P (1988) Effects of slow release carbohydrates in the form of bean flakes on the evolution of hunger and satiety in man. Appetite 10, 1-11.

18. Panlasigui LN, Panlilio LM \& Madrid JC (1995) Glycaemic response in normal subjects to five different legumes commonly used in the Philippines. Int J Food Sci Nutr 46, 155-160.

19. Potter JG, Coffman KP, Reid RL, et al. (1981) Effect of test meals of varying dietary fiber content on plasma insulin and glucose response. Am J Clin Nutr 34, 328-334.

20. Tappy L, Wursch P, Randin JP, et al. (1986) Metabolic effect of pre-cooked instant preparations of bean and potato in normal and in diabetic subjects. Am J Clin Nutr 43, 30-36.

21. Thompson SV, Winham DM \& Hutchins AM (2012) Bean and rice meals reduce postprandial glycemic response in adults with type 2 diabetes: a cross-over study. Nutr J (in press).

22. Torsdottir I, Alpsten M, Andersson H, et al. (1989) Gastric emptying and glycemic response after ingestion of mashed bean or potato flakes in composite meals. Am J Clin Nutr 50, 1415-1419.

23. Tovar J, Granfeldt Y \& Bjorck I (1992) Effect of processing on blood glucose and insulin responses to starch in legumes. J Agric Food Chem 40, 1846-1851.

24. Eckel RH, Kahn R, Robertson RM, et al. (2006) Preventing cardiovascular disease and diabetes: a call to action from the American Diabetes Association and the American Heart Association. Diabetes Care 29, 1697-1699.

25. Jenkins DJ, Kendall CW, Augustin LS, et al. (2002) Glycemic index: overview of implications in health and disease. $A m \mathrm{~J}$ Clin Nutr 76, 266S-273S.

26. Barclay AW, Petoca P, McMillan-Price J, et al. (2008) Glycemic index, glycemic load, and chronic disease risk-a meta-analysis of observational studies. Am J Clin Nutr 87, 627-637.

27. Venn BJ \& Mann JI (2004) Cereal grain, legumes and diabetes. Eur J Clin Nutr 58, 1443-1461.

28. Thomas D \& Elliott EJ (2009) Low glycaemic index, or low glycaemic load, diets for diabetes mellitus The Cochrane Database of Systematic Reviews 2009, issue 1, CD006296. http://www.mrw.interscience.wiley.com/cochrane/ clsysrev/articles/CD006296/frame.html

29. Brand-Miller JC, Thomas M, Swan V, et al. (2003) Physiological validation of the concept of glycemic load in lean young adults. $J$ Nutr 133, 2728-2732.

30. Opperman AM, Venter CS, Oosthuizen W, et al. (2004) Meta-analysis of the health effects of using the glycaemic index in meal-planning. BrJ Nutr 92, 367-381.

31. Anderson JW, Story L, Sieling B, et al. (1984) Hypocholesterolemic effects of oat-bran or bean intake for hypercholesterolemic men. Am J Clin Nutr 40, 1146-1155.

32. Cobiac L, McArthur R \& Nestel PJ (1990) Can eating baked beans lower plasma cholesterol? Eur J Clin Nutr $4 \mathbf{4}$, 819-822.

33. Fleming SE \& Shaheen SM (1988) Repeated consumption of high-fiber breakfasts: effects on postprandial glucose and insulin responses after breakfast and lunch. Am J Clin Nutr 47, 859-867.

34. Jang Y, Lee JH, Kim OY, et al. (2001) Consumption of whole grain and legume powder reduces insulin demand, lipid peroxidation, and plasma homocysteine concentrations in patients with coronary artery disease: randomized controlled clinical trial. Arterioscler Thromb Vasc Biol 21, 2065-2071.

35. Winham DM \& Hutchins AM (2007) Baked bean consumption reduces total cholesterol in mildly hypercholesterolemic men and women. Nutr Res 27, 380-386.
36. Winham DM, Hutchins AM \& Johnston CS (2007) Pinto bean consumption reduces biomarkers for heart disease risk. J Am Coll Nutr 26, 243-249.

37. Wursch P, Acheson K, Koellreutter B, et al. (1988) Metabolic effects of instant bean and potato over 6 hours. Am J Clin Nutr 48, 1418-1423.

38. Rizkalla SW, Bellisle F \& Slama G (2002) Health benefits of low glycaemic index foods, such as pulses, in diabetic patients and healthy individuals. Br J Nutr 88, Suppl. 3, S255-S262.

39. Kitahara CM (2010) Low-glycemic load diets: how does the evidence for prevention of disease measure up? J Am Diet Assoc 110, 1818-1819.

40. Leeds AR (2002) Glycemic index and heart disease. Am J Clin Nutr 76, 286S-289S.

41. Kelly SAM, Frost G \& Whittaker V, et al. (2004) Low glycaemic index diets for coronary heart disease The Cochrane Database of Systematic Reviews, 2004, issue 4, CD004467. http://www.mrw.interscience.wiley.com/cochrane/ clsysrev/articles/CD004467/frame.html

42. McCrory MA, Hamaker BR, Lovejoy JC, et al. (2010) Pulse consumption, satiety, and weight management. Adv Nutr 1, 17-30.

43. Williams PG, Grafenauer SJ \& O'Shea JE (2008) Cereal grains, legumes, and weight management: a comprehensive review of the scientific evidence. Nutr Rev $\mathbf{6 6}$ 171-182.

44. Anderson JW, Gustafson NJ, Spencer DB, et al. (1990) Serum lipid response of hypercholesterolemic men to single and divided doses of canned beans. Am J Clin Nutr 51, 1013-1019.

45. Anderson JW \& Major AW (2002) Pulses and lipaemia, short- and long-term effect: potential in the prevention of cardiovascular disease. Br J Nutr 88, Suppl. 3, S263-S271.

46. Anderson JW, Smith BM \& Washnock CS (1999) Cardiovascular and renal benefits of dry bean and soybean intake. Am J Clin Nutr 70, 464S-474S.

47. Nestel P, Cehun M \& Chronopoulos A (2004) Effects of long-term consumption and single meals of chickpeas on plasma glucose, insulin, and triacylglycerol concentrations. Am J Clin Nutr 79, 390-395.

48. Davignon J \& Ganz P (2004) Role of endothelial dysfunction in atherosclerosis. Circulation 109, III-27-III-32.

49. Hu Y, Block G, Norkus EP, et al. (2006) Relations of glycemic index and glycemic load with plasma oxidative stress markers. Am J Clin Nutr 84, 70-76.

50. Ceriello A, Esposito K, Piconi L, et al. (2008) Glucose "peak" and glucose "spike": impact on endothelial function and oxidative stress. Diabetes Res Clin Pract 82, 262-267.

51. Hu FB, Rimm EB, Stampfer MJ, et al. (2000) Prospective study of major dietary patterns and risk of coronary heart disease in men. Am J Clin Nutr 72, 912-921.

52. Stoll BA (1999) Western nutrition and the insulin resistance syndrome: a link to breast cancer. Eur J Clin Nutr $\mathbf{5 3}$, 83-87.

53. Kaaks R (1996) Nutrition, hormones, and breast cancer: is insulin the missing link? Cancer Causes Control 7, 605-625.

54. Augustin LS, Dal Maso L, La Vecchia C, et al. (2001) Dietary glycemic index and glycemic load, and breast cancer risk: a case-control study. Ann Oncol 12, 1533-1538.

55. Augustin LS, Galeone C, Dal Maso L, et al. (2004) Glycemic index, glycemic load and risk of prostate cancer. Int $J$ Cancer 112, 446-450.

56. Augustin LS, Gallus S, Bosetti C, et al. (2003) Glycemic index and glycemic load in endometrial cancer. Int $J$ Cancer 105, 404-407. 
57. Augustin LS, Gallus S, Negri E, et al. (2004) Glycemic index, glycemic load and risk of gastric cancer. Ann Oncol 15, 581-584.

58. Augustin LS, Polesel J, Bosetti C, et al. (2003) Dietary glycemic index, glycemic load and ovarian cancer risk: a casecontrol study in Italy. Ann Oncol 14, 78-84.

59. Cho E, Spiegelman D, Hunter CJ, et al. (2003) Premenopausal dietary carbohydrate, glycemic index, glycemic load, and fiber in relation to risk of breast cancer. Cancer Epidemiol Biomarkers Prev 12, 1153-1158.

60. Dong JY \& Qin LQ (2011) Dietary glycemic index, glycemic load, and risk of breast cancer: meta-analysis of prospective cohort studies. Breast Cancer Res Treat 126, 287-294.

61. Flood A, Peters U, Jenkins DJ, et al. (2006) Carbohydrate, glycemic index, and glycemic load and colorectal adenomas in the Prostate, Lung, Colorectal, and Ovarian Screening Study. Am J Clin Nutr 84, 1184-1192.

62. Folsom AR, Demissie Z \& Harnack L (2003) Glycemic index, glycemic load, and incidence of endometrial cancer: the Iowa Women's Health Study. Nutr Cancer $\mathbf{4 6}$, $119-124$.

63. Franceschi S, Dal Maso L, Augustin L, et al. (2001) Dietary glycemic load and colorectal cancer risk. Ann Oncol 12, $173-178$.

64. Galeone C, Pelucchi C, Maso LD, et al. (2009) Glycemic index, glycemic load and renal cell carcinoma risk. Ann Oncol 20, 1881-1885.

65. Gnagnarella P, Gandini S, La Vecchia C, et al. (2008) Glycemic index, glycemic load, and cancer risk: a meta-analysis. Am J Clin Nutr 87, 1793-1801.

66. Hartman TJ, Albert PS, Zhang Z, et al. (2010) Consumption of a legume-enriched, low-glycemic index diet is associated with biomarkers of insulin resistance and inflammation among men at risk for colorectal cancer. J Nutr 140, 60-67.

67. Higginbotham S, Zhang ZF, Lee IM, et al. (2004) Dietary glycemic load and breast cancer risk in the Women's Health Study. Cancer Epidemiol Biomarkers Prev 13, 65-70.

68. Higginbotham S, Zhang ZF, Lee IM, et al. (2004) Dietary glycemic load and risk of colorectal cancer in the Women's Health Study. J Natl Cancer Inst 96, 229-233.

69. Jonas CR, McCullough ML, Teras LR, et al. (2003) Dietary glycemic index, glycemic load, and risk of incident breast cancer in postmenopausal women. Cancer Epidemiol Biomarkers Prev 12, 573-577.

70. Meinhold CL, Dodd KW, Jiao L, et al. (2010) Available carbohydrates, glycemic load, and pancreatic cancer: is there a link? Am J Epidemiol 171, 1174-1182.

71. Mulholland HG, Murray LJ, Cardwell CR, et al. (2008) Dietary glycaemic index, glycaemic load and breast cancer risk: a systematic review and meta-analysis. Br J Cancer 99, $1170-1175$

72. Mulholland HG, Murray LJ, Cardwell CR, et al. (2008) Dietary glycaemic index, glycaemic load and endometrial and ovarian cancer risk: a systematic review and meta-analysis. Br J Cancer 99, 434-441.

73. Mulholland HG, Murray LJ, Cardwell CR, et al. (2009) Glycemic index, glycemic load, and risk of digestive tract neoplasms: a systematic review and meta-analysis. $\mathrm{Am} \mathrm{J}$ Clin Nutr 89, 568-576.

74. Potischman N, Swanson CA, Coates RJ, et al. (1999) Intake of food groups and associated micronutrients in relation to risk of early-stage breast cancer. Int J Cancer 82, 315-321.

75. Rossi M, Lipworth L, Polesel J, et al. (2010) Dietary glycemic index and glycemic load and risk of pancreatic cancer: a case-control study. Ann Epidemiol 20, 460-465.
76. Shikany JM, Flood AP, Kitahara CM, et al. (2011) Dietary carbohydrate, glycemic index, glycemic load, and risk of prostate cancer in the Prostate, Lung, Colorectal, and Ovarian Cancer Screening Trial (PLCO) cohort. Cancer Causes Control 22, 995-1002.

77. Shikany JM, Redden DT, Neuhouser ML, et al. (2011) Dietary glycemic load, glycemic index, and carbohydrate and risk of breast cancer in the Women's Health Initiative. Nutr Cancer 63, 899-907.

78. Silvera SA, Jain M, Howe GR, et al. (2005) Dietary carbohydrates and breast cancer risk: a prospective study of the roles of overall glycemic index and glycemic load. Int $J$ Cancer 114, 653-658.

79. Silvera SA, Rohan TE, Jain M, et al. (2005) Glycemic index, glycemic load, and pancreatic cancer risk (Canada). Cancer Causes Control 16, 431-436.

80. Simon MS, Shikany JM, Neuhouser ML, et al. (2010) Glycemic index, glycemic load, and the risk of pancreatic cancer among postmenopausal women in the women's health initiative observational study and clinical trial. Cancer Causes Control 21, 2129-2136.

81. Strayer L, Jacobs DR Jr, Schairer C, et al. (2007) Dietary carbohydrate, glycemic index, and glycemic load and the risk of colorectal cancer in the BCDDP cohort. Cancer Causes Control 18, 853-863.

82. United States Department of Health and Human Services and United States Department of Agriculture (2005) Dietary Guidelines for Americans 2005. Washington, DC: US Government Printing Office.

83. Messina MJ (1999) Legumes and soybeans: overview of their nutritional profiles and health effects. Am J Clin Nutr 70, S439-S450.

84. Aykroyd WR, Doughty J \& Walker A (1982) Legumes in Human Nutrition, 2nd ed. Rome: FAO.

85. Halvorsen BL, Holte K, Myhrstad MCW, et al. (2002) A systematic screening of total antioxidants in dietary plants. J Nutr 132, 461-471.

86. Kalogeropoulos N, Chiou A, Ioannou M, et al. (2010) Nutritional evaluation and bioactive microconstituents (phytosterols, tocopherols, polyphenols, triterpenic acids) in cooked dry legumes usually consumed in Mediterranean countries. Food Chem 121, 682-690.

87. Lucier G \& Jerardo A (2006) Vegetables and Melons Outlook. Electronic Outlook Report from the Economic Research Service no. VGS-317. Washington, DC: USDA Economic Research Service.

88. Mitchell DC, Lawrence FR, Hartman TJ, et al. (2009) Consumption of dry beans, peas, and lentils could improve diet quality in the US population. J Am Diet Assoc 109, 909-913.

89. Bednar GE, Patil AR, Murray SM, et al. (2001) Starch and fiber fractions in selected food and feed ingredients affect their small intestinal digestibility and fermentability and their large bowel fermentability in vitro in a canine model. J Nutr 131, 276-286.

90. Thorne MJ, Thompson LU \& Jenkins DJ (1983) Factors affecting starch digestibility and the glycemic response with special reference to legumes. Am J Clin Nutr 38, 481-488.

91. Institute of Medicine (2005) Dietary References Intakes for Energy, Carbohydrate, Fiber, Fat, Fatty Acids, Cholesterol, Protein, and Amino Acids (Macronutrients), 1st ed. Washington, DC: National Academies Press.

92. Noah L, Guillon F, Bouchet B, et al. (1998) Digestion of carbohydrate from white beans (Phaseolus vulgaris L.) in healthy humans. J Nutr 128, 977-985. 
93. Wolever TMS \& Jenkins DJA (2001) Effect of dietary fiber and foods on carbohydrate metabolism. In CRC Handbook of Dietary Fiber in Human Nutrition, 3rd ed., pp. 321-362 [GA Spiller, editor]. Boca Raton, FL: CRC Press.

94. Jenkins DJ \& Jenkins AL (1985) Dietary fiber and the glycemic response. Proc Soc Exp Biol Med 180, 422-431.

95. Jenkins DJ, Kendall CW, McKeown-Eyssen G, et al. (2008) Effect of a low-glycemic index or a high-cereal fiber diet on type 2 diabetes: a randomized trial. JAMA $\mathbf{3 0 0}$, 2742-2753.

96. Brownlee IA, Havler ME, Dettmar PW, et al. (2003) Colonic mucus: secretion and turnover in relation to dietary fibre intake. Proc Nutr Soc 62, 245-249.

97. Cohn JS, Kamili A, Wat E, et al. (2010) Reduction in intestinal cholesterol absorption by various food components: mechanisms and implications. Atheroscler Suppl 11, 45- 48 .

98. Fuse K, Bamba T \& Hosoda S (1989) Effects of pectin on fatty acid and glucose absorption and on thickness of unstirred water layer in rat and human intestine. Dig Dis Sci 34, $1109-1116$
99. Alli I \& Baker RE (1980) Constitution of leguminous seeds: the microscopic structure of proteins isolated from phaseolus beans. J Sci Food Agric 31, 1316-1322.

100. Behall KM, Scholfield DJ \& Canary JC (1988) Effect of starch structure on glucose and insulin responses in adults. $\mathrm{Am} \mathrm{J}$ Clin Nutr 47, 428-432.

101. Yoon JH, Thompson LU \& Jenkins DJA (1983) The effect of phytic acid on in vitro rate of starch digestibility and blood glucose response. Am J Clin Nutr 38, 835-842.

102. Thompson LU, Button CL \& Jenkins DJ (1987) Phytic acid and calcium affect the in vitro rate of navy bean starch digestion and blood glucose response in humans. $A m \mathrm{~J}$ Clin Nutr 46, 467-473.

103. Kallio P, Kolehmalnen M, Laaksonen DE, et al. (2007) Dietary carbohydrate modifcation induces alterations in gene expression in abdominal subcutaneous adipose tissue in person with the metabolic syndrome: the FUNGENUT Study. Am J Clin Nutr 85, 1417-1427.

104. McAuley KA, Williams SM, Mann JI, et al. (2002) Intensive lifestyle changes are necessary to improve insulin sensitivity: a randomized controlled trial. Diabetes Care 25, 445-452. 